\title{
PENGGUNAAN 2,4-D UNTUK INDUKSI KALUS KLON KAKAO UNGGUL SULAWESI 1
}

\author{
Yulianti Rasud ${ }^{1}$, Mohammad Habil ${ }^{2}$, Tony Tony $^{3}$ \\ 1,2,3 Sekolah Tinggi Ilmu Pertanian Mujahidin Tolitoli Jl. DR. Sam Ratulangi No. 51 \\ Tolitoli, Sulawesi Tengah (94515) \\ Email: yulirasud.stip@gmail.com
}

Receive: 15 September 2019

Accepted: 12 Oktober 2019

\begin{abstract}
The multiplication of cocoa clones in conventional Sulawesi has not yet been able to fulfill the demand for large quantities of seeds because it is limited by the number of shoots and branches ready to be tapped, connected and oculated and takes longer to produce large quantities of seeds. One alternative in overcoming this problem is plant proragation using tussue culture techniques. The aim of this experiment was to determine the appropriate of 2,4$\mathrm{D}$ for callus induction of superior cocoa clones Sulawesi via in vitro culture. This experiment used Completely Randomized Design with five treatments, namely 0.50 ppm 2,4-D, 0.75 ppm 2,4-D, 1.00 ppm 2,4-D, 1.25 ppm 2,4-D and $1.50 \mathrm{ppm}$ 2,4-D. Parameters observed consisted of the time, percentage, color and texture of calli. Data was analized by using analysis of variance and differences between mean treatments were determined by Honestly Significant Difference Test at 5\% level. Results of this experiment indicated that the ability of different callus induction at various concentrations of 2,4-D for superior cocoa clones in Sulawesi 1 was tried. it was obtained the quickest callus formation at concentration $0.50 \mathrm{ppm} 2,4-\mathrm{D}$ namely average $4.22 \mathrm{WAC}$ with the percentage of callus formation was up to $99,33 \%$.
\end{abstract}

Keywords: Callus Induction, Clones Sulawesi 1, 2,4-D

\begin{abstract}
ABSTRAK
Perbanyakan klon kakao Sulawesi secara konvensional saat ini belum dapat memenuhi permintaan bibit dalam jumlah besar karena sangat dibatasi oleh jumlah tunas dan cabang yang siap disetek, disambung, dan diokulasi serta dibutuhkan waktu yang lebih lama untuk menghasilkan bibit dalam jumlah besar. Salah satu alternatif dalam mengatasi masalah tersebut adalah perbanyakan tanaman dengan menggunakan teknik kultur jaringan. Penelitian ini bertujuan untuk memperoleh protokol yang tepat dalam menginduksi kalus sebagai upaya awal dalam perbanyakan tanaman kakao melalui embryogenesis. Penelitian ini menggunakan Rancangan Acak Lengkap (RAL) dengan 5 level perlakuan yaitu 0,50 ppm 2,4-D, 0,75 ppm 2,4-D, 1,00 ppm 2,4-D, 1,25 ppm 2,4-D dan 1,50 ppm 2,4-D. Pengamatan dilakukan terhadap saat muncul kalus, persentase eksplan berkalus, warna kalus dan tekstur kalus. Data diolah dengan analisis ragam dan perbedaan antar perlakuan ditentukan dengan Uji Beda Nyata Jujur pada taraf 5\%. Hasil penelitian menunjukkan kemampuan induksi kalus berbeda pada berbagai konsentrasi 2,4-D untuk klon kakao unggul Sulawesi 1 yang dicobakan. Saat muncul kalus paling cepat diperoleh pada konsentrasi 0,5 ppm 2,4-D yaitu rata-rata 16,67 HST dengan persentase pembentukan kalus tertinggi mencapai 99,33\%. Selanjutnya, warna dan tekstur kalus yang dihasilkan yaitu remah putih dan remah kecoklatan.
\end{abstract}

Kata Kunci: Induksi Kalus, Klon Sulawesi 1, 2,4-D.

\section{PENDAHULUAN}

Kakao (Theobroma cacao L.) merupakan salah satu jenis tanaman perkebunan yang terus mendapat perhatian untuk dikembangkan. Upaya pengembangan tanaman kakao disamping masih diarahkan pada peningkatan populasi juga telah banyak diarahkan pada peningkatan jumlah produksi dan mutu hasil. Adapun aspek yang paling diperhatikan dalam usaha peningkatan jumlah produksi dan mutu hasil adalah penggunaan jenis-jenis kakao unggul dalam pembudidayaan tanaman kakao. Saat ini terdapat sejumlah jenis kakao unggul yang sering digunakan dalam budidaya kakao, antara lain klon Sulawesi 1 dan Sulawesi 2 (Direktorat Jenderal Perkebunan, 2009).

Klon-klon kakao unggul, terutama klon Sulawesi 1 dan Sulawesi 2 sudah cukup banyak digunakan petani di daerah Sulawesi Tengah. Klon-klon tersebut telah menjadi klon pilihan dalam perbanyakan bahan tanaman kakao. Perbanyakan klon kakao Sulawesi secara konvensional saat ini belum dapat memenuhi permintaan bibit dalam jumlah besar karena 
sangat dibatasi oleh jumlah tunas dan cabang yang siap disetek, disambung, dan diokulasi serta dibutuhkan waktu yang lebih lama untuk menghasilkan bibit dalam jumlah besar. salah satu alternatif dalam mengatasi masalah tersebut adalah perbanyakan tanaman dengan menggunakan teknik kultur jaringan.

Kultur jaringan merupakan suatu teknik mengembangbiakkan bagian tanaman (eksplan) di dalam media buatan yang steril dan dapat dilakukan dengan dua cara yaitu organogenesis dan embriogenesis. Pembentukan embrio somatik (SE) dapat secara langsung maupun tidak langsung. Embriogenesis somatik langsung adalah pembentukan embrio somatik atau jaringan embriogenik secara langsung dari eksplan tanpa melalui fase pembentukan kalus. Sebaliknya, pada embriogenesis somatik tidak langsung proses pembentukan embrio somatik didahului melalui fase kalus. Pada embriogenesis somatik tidak langsung, induksi kalus merupakan faktor penentu keberhasilan untuk perbanyakan tanaman (Ibrahim et al., 2010). Induksi kalus embriogenik merupakan langkah awal untuk perbanyakan tanaman melalui teknik ES secara tidak langsung. Kalus merupakan kumpulan massa sel yang tidak terorganisasi yang terbentuk akibat pembelahan sel yang terjadi secara terus menerus. Pembelahan terjadi di permukaan sel sebagai respon stres akibat pelukaan (Ikeuchi et al. 2013). Hormon auksin berperan dalam perkembangan sel, menaikkan tekanan osmotik, dan meningkatkan permeabilitas sel terhadap air sehingga air dapat masuk ke dalam sel dengan meningkatkan volume sel (Kartikasari, 2013). Salah satu hormon auksin yang sering digunakan dalam menginduksi kalus adalah 2,4-D. 2,4-D efektif untuk merangsang pembentukan kalus karena aktivitas yang kuat untuk memacu proses diferensiasi sel, organogenesis dan menjaga pertumbuhan kalus (Sitinjak et al., 2015). Penggunaan 2,4-D pada media kultur jaringan telah banyak dilaporkan. Avivi et al., (2010), menyatakan penambahan 2,4-D pada media MS dapat menstimulasi pembentukan kalus dari eksplan staminodia bunga kakao klon Sca 6 . Selanjutnya, Arianto (2013), melaporkan penggunaan 2,4-D pada konsentrasi 1 ppm baik pada klon Sulawesi 1 maupun klon Sulawesi 2 merupakan konsentrasi yang lebih baik untuk menginduksi kalus dengan persentase pembentukan kalus mencapai $100 \%$. Tujuan penelitian ini adalah untuk menentukan konsentrasi 2,4-D yang sesuai terhadap induksi kalus klon kakao unggul Sulawesi 1

\section{Lokasi Penelitian}

\section{BAHAN DAN METODE}

Penelitian ini dilaksanakan di Laboratorium Bioteknologi Tanaman, Fakultas Pertanian Universitas Tadulako Palu, pada bulan Mei hingga Agustus 2014.

\section{Jenis dan Desain Penelitian}

Penelitian ini menggunakan Rancangan Acak Lengkap (RAL) dengan perlakuan yang dicobakan konsentrasi 2,4-D yang dari lima level, yaitu : 0,50 ppm, 0,75 ppm, 1,00 ppm, 1,25 $\mathrm{ppm}$, dan 1,50 ppm. Setiap perlakuan diulang sebanyak tiga kali sehingga terdapat 15 unit percobaan. Tiap unit percobaan menggunakan 5 eksplan, dengan demikian terdapat total 75 eksplan. Guna mengetahui pengaruh perlakuan yang dicobakan, data yang diperoleh dianalisis menggunakan sidik ragam. Hasil sidik ragam yang menunjukkan pengaruh nyata, maka dilanjutkan menggunakan uji lanjut Beda Nyata Jujur (BNJ) taraf 5\%

\section{Alat dan Bahan Penelitian}

Peralatan yang digunakan pada penelitian ini adalah batang pengaduk, gelas stainless, pemanas listrik (hot plate), magnetic stirrer, destilasi air, timbangan analitik, corong, gelas ukur, kelas kimia, Erlenmeyer, pipet, autoclave, oven listrik, handspayer, cawan Petri, lampu Bunsen, gunting, pinset, scalpel, blade, rotary shaker, $\mathrm{pH}$ meter, Laminar air flow cabinet dan parafilm. Eksplan yang digunakan adalah staminodia bunga kakao dari klon Sulawesi 1 yang masih kuncup, diperoleh dari kebun percobaan UNTAD di Palolo. Bahan lain yang digunakan yaitu bahan kimia sesuai komposisi media MS (Murashige dan Skoog), glukosa, phytagel, zat pengatur tumbuh 2,4-D, alkohol $70 \%$, aquades steril, chlorox, detergen, spritus, tissue dan kertas label.

\section{Pelaksanaan Penelitian}

Pelaksanaan penelitian ini meliputi kegiatan sterilisasi alat dan aquades, pembuatan dan strerilisasi media, sterilisasi bahan tanaman, penanaman dan pemeliharaan. Seluruh peralatan yang akan digunakan terlebih dahulu disterilkan untuk menghindari terjadinya kontaminasi. Alatalat yang digunakan dicuci terlebih dahulu dengan detergen, dibilas, kemudian dikeringkan. Setelah kering, alat-alat seperti cawan Petri, corong, gelas ukur, scalpel, pinset, batang pengaduk dan pipet dibungkus rapi dengan kertas. Kemudian seluruh alat tersebut disterilkan dengan menggunakan autoklaf pada suhu $121^{\circ} \mathrm{C}$ dan tekanan 17,5 psi selama satu jam. 
Hal ini juga berlaku untuk sterilisasi aquades, yaitu menggunakan suhu dan tekanan yang sama.

Langkah awal dalam pembuatan media adalah pembuatan larutan stok. Larutan stok dibuat sesuai komposisi media MS. Pembuatan media dimulai dengan mengambil larutan stok media MS sesuai dengan takaran, kemudian larutan tersebut dimasukkan ke dalam labu takar kapasitas 1L. Setelah semua komponen larutan stock dimasukkan ke dalam labu takar, kemudian ditambahkan $30 \mathrm{~g}$ sukrosa dan dicampurkan dengan zat pengatur tumbuh sesuai perlakuan $\mathrm{H} 1$ $=0,50$ ppm 2,4-D, H2 = 0,75 ppm 2,4-D, H3 = 1,00 ppm 2,4-D, H4 = 1,25 ppm 2,4-D, H5 = 1,50 ppm 2,4-D. Selanjutnya, ditambahkan aquades hingga volume larutan mencapai 1 liter. Seluruh media ditetapkan $\mathrm{pH}$ 5,8. Media tersebut selanjutnya dipanaskan menggunakan hot plate pada suhu sekitar 800C setelah ditambahkan $8 \mathrm{~g}$ agar. Sambil dipanaskan, larutan media tersebut diaduk hingga semua agar terlarut. Pemanasan dihentikan saat media menjadi bening. Media kemudian dituang ke botol kultur dengan volume $25 \mathrm{ml}$ per botol. Botol tersebut ditutup rapat dengan almunium foil/plastik dan dilabel, lalu disterilisasi dalam autoklaf pada tekanan 17,5 psi selama 15 menit.

Eksplan yang di gunakan adalah staminodia bunga kakao yang masih kuncup. Eksplan yang telah disterilisasi selanjutnya diletakkan dalam cawan petri. Eksplan tersebut diisolasi, kemudian ditanam pada media inisiasi. Setelah melakukan penanaman, semua botol kultur ditutup dengan tutup plastik lalu diketatkan dengan karet gelang dan diberi label sesuai perlakuan. Seluruh kegiatan penanaman dilakukan di dekat lampu bunsen dalam Laminar Air Flow Cabinet. Setelah selesai melakukan penanaman, semua botol kultur diletakkan pada rak kultur dalam ruang pemeliharaan gelap. Ruang pemeliharaan harus selalu steril dan dijaga kebersihannya. Suhu ruangan dipertahankan antara $22^{\circ} \mathrm{C}$ sampai $26^{\circ} \mathrm{C}$. Peubah yang diamati meliputi saat muncul kalus, persentase eksplan membentuk kalus, warna kalus dan tekstur kalus.

\section{Saat Muncul Kalus}

\section{HASIL DAN PEMBAHASAN}

Hasil sidik ragam menunjukkan bahwa masingmasing perlakuan 2,4-D yang dicobakan berpengaruh sangat nyata terhadap saat muncul kalus. Rata- rata saat muncul kalus dari berbagai perlakuan yang dicobakan disajikan pada Tabel 1.
Tabel 1. Saat Munculnya Kalus dalam Hari

Setelah Tanam (HST)

\begin{tabular}{ccc}
\hline Perlakuan & Rata-Rata & BNJ 5\% \\
\hline 0.50 ppm 2.4-D & $16,67 \mathrm{e}$ & \\
$0.75 \mathrm{ppm} 2.4-\mathrm{D}$ & $19,67 \mathrm{~d}$ & \\
$1.00 \mathrm{ppm} 2.4-\mathrm{D}$ & $24,00 \mathrm{c}$ & 0.98 \\
$1.25 \mathrm{ppm} 2.4-\mathrm{D}$ & $26,00 \mathrm{~b}$ & \\
$1.50 \mathrm{ppm} 2.4-\mathrm{D}$ & $27,00 \mathrm{a}$ & \\
\hline
\end{tabular}

Keterangan: Angka yang diikuti oleh huruf yang sama pada kolom menunjukkan tidak berbeda nyata pada taraf uji BNJ 5\%.

Sesuai hasil uji BNJ 5\% pada Tabel 1, diketahui bahwa pemberian 2,4-D pada konsentrasi yang berbeda memberikan perbedaan terhadap saat muncul kalus. Pembentukan kalus pada eksplan staminodia kakao paling cepat diperoleh pada konsentrasi $0,50 \mathrm{ppm}$ yakni hanya 16,67 HST. Pembentukan kalus menjadi lebih lambat pada konsentrasi yang lebih tinggi $(0,75$ $1,50 \mathrm{ppm} 2,4-\mathrm{D})$ yaitu rata-rata $19,67-27,00$ HST.

Berdasarkan data tersebut, maka diketahui bahwa konsentrasi 0,50 ppm 2,4-D merupakan konsentrasi yang sesuai untuk induksi kalus pada eksplan staminodia kakao. Pada konsentrasi tersebut diperoleh suatu kesesuaian konsentrasi antara zat pengatur tumbuh yang diberikan (eksogen) dan fitohormon (endogen) dalam memacu pembelahan sel-sel pada jaringan staminodia kakao. Munculnya kalus pada eksplan diawali dari bagian bekas irisan pada pangkal staminodia, dan kemudian. menyebar hingga keseluruh bagian staminodia. Sebelum membentuk kalus, eksplan menunjukkan perubahan fisik. Pada awalnya eksplan berbentuk lurus kemudian berubah menjadi bengkok dan membesar serta berwarna lebih merah dibandingkan dengan sebelum eksplan dikulturkan. Zat pengatur tumbuh pada media tanam akan berdifusi ke dalam jaringan tanaman melalui pangkal eksplan yang terluka akibat irisan. Adanya pelukaan ini memudahkan 2,4-D berdifusi ke dalam jaringan tanaman. RoblesMartinez et al. (2016), menyatakan penggunaan auksin 2,4- D dapat memacu pertumbuhan kalus, auksin berupa 2,4-D dapat menaikkan tekanan osmotik, meningkatkan permeabilitas sel terhadap air, menyebabkan pengurangan tekanan pada dinding sel, meningkatkan sintesis protein, meningkatkan plastisitas, dan pengembangan dinding sel. Dengan berdifusinya 2,4-D ke dalam jaringan tanaman, terutama melalui jaringan yang terluka tersebut, akan menstimulasi pembelahan sel terutama sel-sel yang berada di 
sekitar daerah yang terluka. Awal munculnya kalus ditandai dengan munculnya gumpalan selsel yang berwarna putih. Selanjutnya gumpalangumpalan tersebut berkembang membentuk massa sel yang disebut kalus. Pembentukan kalus pada media yang ditambahkan 0,5 ppm 2,4-D ditampilkan pada Gambar 1.

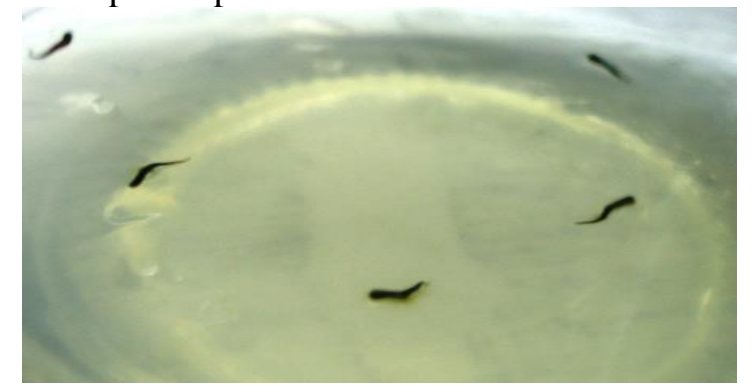

Gambar 1. Pembentukan Kalus eksplan

Staminodia pada Klon Kakao Unggul Sulawesi pada Pemberian 0.50 ppm 2,4-D (3 MST)

\section{Persentase Eksplan Membentuk Kalus}

Hasil sidik ragam menunjukkan bahwa perlakuan yang dicobakan berpengaruh nyata terhadap persentase eksplan membentuk kalus. Rata- rata persentase eksplan membentuk kalus dari berbagai perlakuan yang dicobakan disajikan pada Tabel 2.

Tabel 2. Persentase Eksplan Berkalus (8 MST).

\begin{tabular}{ccc}
\hline PERLAKUAN & RATA-RATA & BNJ 5\% \\
\hline 0.50 ppm 2.4-D & $100,00 \mathrm{~b}$ & \\
0.75 ppm 2.4-D & $86,67 \mathrm{ab}$ & \\
$1.00 \mathrm{ppm} 2.4-\mathrm{D}$ & $86,67 \mathrm{ab}$ & 24,06 \\
$1.25 \mathrm{ppm} 2.4-\mathrm{D}$ & $80,00 \mathrm{ab}$ & \\
1.50 ppm 2.4-D & $73,33 \mathrm{a}$ & \\
\hline
\end{tabular}

Keterangan: Angka yang diikuti oleh huruf yang sama pada kolom menunjukkan tidak berbeda nyata pada taraf uji BNJ 5\%.

Sesuai hasil uji BNJ 5\% pada Tabel 2, menunjukkan bahwa pemberian 0,5 ppm 2,4-D memberikan perbedaan terhadap persentase pembentukan kalus hingga minggu kedelapan setelah tanam pada konsentrasi $1,50 \mathrm{ppm}$ tetapi tidak berbeda dengan konsentrasi lainnya. Sesuai data pada Tabel 2, dapat dilihat bahwa persentase pembentukan kalus dari berbagai perlakuan yang dicobakan berkisar antara 73,00\% - 100\%. Persentase Pembentukan kalus tertinggi diperoleh pada media yang ditambahkan 0,50 ppm 2,4-D yaitu mencapai 100\%. Persentase pembentukan kalus menurun bila konsentrasi 2,4-D semakin ditingkatkan (0,75-1,50 ppm). Pemberian 2,4-D pada konsentrasi yang terlalu tinggi tidak dapat mempercepat, tetapi justru akan menghambat pertumbuhan kalus dan menyebabkan toksik pada eksplan, sehingga kemampuannya dalam membentuk kalus berkurang (Wijaya et al., 2017). Dari hasil yang diperoleh dengan jelas bahwa penambahan 2,4-D pada konsentrasi yang rendah $(0,50 \mathrm{ppm})$ sudah cukup untuk menstimulasi pembentukan kalus pada eksplan staminodia kakao.

Pembentukan kalus pada media yang ditambahkan 0,5 ppm 2,4-D hingga minggu kedelapan ditampilkan pada Gambar 2.

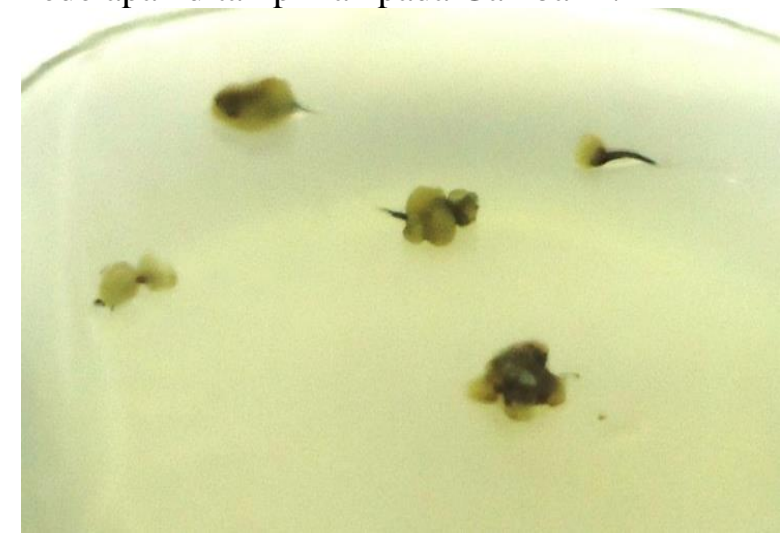

Gambar 2. Pemberian $0.50 \mathrm{ppm}$ 2,4-D pada Klon Kakao Unggul Sulawesi 1

\section{Warna Kalus}

Hasil pengamatan secara visual terhadap perubahan warna kalus pada berbagai konsentrasi 2,4-D dari tiga sampai delapan MST disajikan pada Tabel 3 dan 4.

Tabel 3. Perubahan Warna Kalus pada Berbagai Perlakuan (3-5 MST)

\begin{tabular}{ccclc}
\hline \multirow{2}{*}{ PERLAKUAN } & \multirow{2}{*}{ ULANGAN } & \multicolumn{3}{c}{ MINGGU PENGAMATAN } \\
\cline { 3 - 5 } $0.50 \mathrm{ppm}$ 2,4-D & I & Putih & Putih Kekuningan & Putih Kekuningan \\
& II & Putih & Putih Kekuningan & Putih Kekuningan \\
& III & Putih & Putih Kekuningan & Putih Kekuningan \\
\hline \multirow{2}{*}{$0.75 \mathrm{ppm}$ 2,4-D } & I & Putih & Putih Kekuningan & Putih Kekuningan \\
& II & Putih & Putih Kekuningan & Putih Kekuningan \\
& III & Putih & Putih Kekuningan & Putih Kekuningan \\
\hline \multirow{2}{*}{$1.00 \mathrm{ppm} 2,4-D$} & I & - & Putih & Putih Kekuningan \\
& II & - & Putih & Putih Kekuningan \\
& III & - & Putih & Putih Kekuningan \\
\hline
\end{tabular}




\begin{tabular}{lccll} 
& I & - & Putih & Putih Kekuningan \\
$1.25 \mathrm{ppm} 2,4-\mathrm{D}$ & II & - & Puth & Putih Kekuningan \\
& III & - & Putih & Putih Kekuningan \\
\hline \multirow{3}{*}{$1.50 \mathrm{ppm} 2,4-\mathrm{D}$} & I & - & Putih & Putih Kekuningan \\
& II & - & Putih & Putih Kekuningan \\
& III & - & Putih & Putih Kekuningan \\
\hline
\end{tabular}

Tabel 4. Perubahan Warna Kalus pada Berbagai Perlakuan (6-8 MST)

\begin{tabular}{|c|c|c|c|c|}
\hline \multirow{2}{*}{ PERLAKUAN } & \multirow{2}{*}{ ULANGAN } & \multicolumn{3}{|c|}{ MINGGU PENGAMATAN } \\
\hline & & VI & VII & VIII \\
\hline \multirow{3}{*}{$0.50 \mathrm{ppm} 2,4-\mathrm{D}$} & I & Putih kecoklatan & Putih kecoklatan & Putih Kecoklatan \\
\hline & II & Putih kecoklatan & Putih kecoklatan & Putih Kecoklatan \\
\hline & III & Putih kecoklatan & Putih kecoklatan & Putih Kecoklatan \\
\hline \multirow{3}{*}{$0.75 \mathrm{ppm} 2,4-\mathrm{D}$} & I & Putih kecoklatan & Putih kecoklatan & Putih Kecoklatan \\
\hline & II & Putih kecoklatan & Putih kecoklatan & Putih Kecoklatan \\
\hline & III & Putih kecoklatan & Putih kecoklatan & Putih Kecoklatan \\
\hline \multirow{3}{*}{$1.00 \mathrm{ppm} 2,4-\mathrm{D}$} & I & Putih Kekuningan & Putih kecoklatan & Putih kecoklatan \\
\hline & II & Putih Kekuningan & Putih kecoklatan & Putih kecoklatan \\
\hline & III & Putih Kekuningan & Putih kecoklatan & Putih kecoklatan \\
\hline \multirow{3}{*}{$1.25 \mathrm{ppm} 2,4-\mathrm{D}$} & I & Putih Kekuningan & Putih kecoklatan & Putih kecoklatan \\
\hline & II & Putih Kekuningan & Putih kecoklatan & Putih kecoklatan \\
\hline & III & Putih Kekuningan & Putih kecoklatan & Puth kecoklatan \\
\hline \multirow{3}{*}{$1.50 \mathrm{ppm} 2,4-\mathrm{D}$} & I & Putih Kekuningan & Putih kecoklatan & Putih kecoklatan \\
\hline & II & Putih Kekuningan & Putih kecoklatan & Putih kecoklatan \\
\hline & III & Putih Kekuningan & Putih kecoklatan & Putih kecoklatan \\
\hline
\end{tabular}

Tabel 5. Tekstur kalus pada berbagai perlakuan umur 8 MST

\begin{tabular}{cccc}
\hline & & Ulangan & \\
\cline { 2 - 4 } Perlakuan & I & II & III \\
\hline $0.50 \mathrm{ppm} 2,4-\mathrm{D}$ & Remah & Remah & Remah \\
$0.75 \mathrm{ppm} 2,4-\mathrm{D}$ & Remah & Remah & Remah \\
$1.00 \mathrm{ppm} 2,4-\mathrm{D}$ & Kompak & Kompak & Kompak \\
$1.25 \mathrm{ppm} 2,4-\mathrm{D}$ & Intermediet & Intermediet & Intermediet \\
$1.50 \mathrm{ppm} \mathrm{2,4-D}$ & Kompak & Kompak & Kompak \\
\hline
\end{tabular}

Berdasarkan hasil pengamatan secara visual terhadap warna kalus yang terbentuk pada tiga hingga delapan minggu setelah tanam (Tabel 3 dan 4), warna kalus yang dihasilkan bervariasi mulai dari putih, putih kekuningan dan putih kecoklatan. Kalus berwarna putih dihasilkan pada minggu ketiga pada konsentrasi $0.5 \mathrm{ppm}$ dan $0.75 \mathrm{ppm}$ terkecuali perlakuan $1.00 \mathrm{ppm}$, 1.25 dan 1.50 ppm kalus berwarna putih dihasilkan pada minggu keempat setelah tanam. Selanjutnya, pada minggu keempat beberapa eksplan mengalami perubahan warna kalus dari putih menjadi putih kekuningan. Perubahan warna kalus terjadi hingga delapan minggu setelah tanam tergantung dari masing-masing perlakuan.

Umumnya perubahan warna yang terjadi pada kalus diawali dengan kalus berwarna putih menjadi putih kekuningan kemudian menjadi putih kecoklatan pada 8 MST. Perbadaan warna kalus tersebut menunjukkan tingkat perkembangan kalus yang berbeda-beda.
Menurut Ariati (2012), kalus yang berwarna putih merupakan jaringan embrionik yang belum mengandung kloroplas, tetapi memiliki kandungan butir pati yang tinggi. Semakin tinggi konsentrasi 2,4-D yang ditambahkan dalam media mempengaruhi penurunan kandungan klorofil dan karoten. Penurunan kandungan klorofil ini diduga terjadi karena pengaruh auksin pada metabolisme karbohidrat. Hal ini dapat dilihat pada perubahan warna kalus dari putih menjadi kecoklatan. Selanjutnya, perubahan warna kalus dari putih menjadi kecoklatan disebabkan adanya reaksi antara senyawa yang ada di dalam jaringan ekplan dengan perlakuan yang diberikan. Salah satu senyawa yang mempengaruhi warna kalus yang terbentuk adalah senyawa fenolik. Sitinjak (2015), menyatakan ketika senyawa fenolik terbentuk mengalami oksidasi maka dapat menyebabkan warna coklat pada kalus (Sitinjak et al., 2015). 


\section{Tekstur Kalus}

Berdasarkan hasil pengamatan secara visual terhadap tipe kalus yang terbentuk pada delapan minggu setelah tanam, diperoleh tipe kalus yang bervariasi yaitu remah, kompak dan intermediet. Hasil pengamatan secara visual terhadap tipe kalus pada 8 MST disajikan pada Tabel 5.

Tekstur kalus yang terbentuk dapat dibedakan menjadi kalus dengan tekstur remah (friabel) dan kalus dengan tekstur kompak. Menurut Mahadi et al., (2016), tekstur kalus dibedakan menjadi tiga, yaitu kalus kompak, intermediet, dan remah. Kalus remah ditandai dengan tekstur kalus yang mudah sekali dipisahpisahkan. Bila kalus diambil dengan pinset, secara otomatis sel-sel kalus akan mudah menempel pada pinset. Sebaliknya, kalus kompak berbentuk gumpalan pejal yang sulit dipisah-pisahkan sedangkan massa kalus merupakan kelompok sel-sel yang sebagian kompak dan lainnya remah. Selanjutnya, kalus intermediet merupakan massa kalus yang terdiri dari kelompok sel-sel yang sebagian kompak dan lainnya remah (Rasud, 2012).

Berdasarkan hasil penelitian hingga minggu kedelapan, pemberian 2,4-D pada konsentrasi 0,5 ppm dan 0,75 ppm menghasilkan kalus yang bertekstur remah (putih ; kecoklatan) sedangkan pada konsentrasi 1,0 ppm 2,4-D menghasilkan kalus bertekstur kompak (putih ; kecoklatan). Selanjutnya, pada konsentrasi 1,25 ppm dan 1,50 ppm 2,4-D menghasilkan kalus yang bertekstur kompak dan intermediet (putih ; kecoklatan). Perubahan warna putih menjadi kecoklatan mengikuti pembentukan tekstur kalus. Pembentukan kalus bertekstur remah umumnya diperoleh dari pemberian 2,4-D pada konsentrasi yang lebih rendah (0,50-0,75 ppm). Widyawati (2010), menyatakan bahwa pembentukan kalus remah dipacu oleh adanya hormon auksin endogen yang diproduksi secara internal oleh eksplan yang dikultur.Sedangkan pada konsentrasi yang lebih tinggi (1,00-1,50 ppm) tekstur kalus yang diperoleh adalah kompak dan intermediet. Terbentuknya kalus yang bertekstur kompak diduga karena tingginya konsentrasi auksin (1,00-1,50 2,4-D) yang diberikan sehingga mempengaruhi peningkatan konsentrasi auksin endogen. Selain itu, auksin juga mempengaruhi potensial air dalam sel yang menyebabkan penyerapan air dari medium ke dalam sel meningkat sehingga sel menjadi lebih padat. Wahyuningtyas (2014), melaporkan bahwa pemberian 2,4-D pada konsentrasi tinggi (4 mg/L) menghasilkan kalus bertekstur kompak dan berwarna putih pada akasia.

Berdasarkan dari hasil tekstur kalus yang dihasilkan maka kalus yang bertipe remah mencirikan sebagai kalus yang embriogenik. Kalus embriogenik merupakan kalus yang diharapkan mampu berkembang menjadi embrio somatik. Kalus yang embriogenik biasanya ditandai dengan kalus yang berwarna putih kuning, mengkilat dan, remah (mudah dipisahkan membentuk fragmen), sedangkan kalus berwarna putih merupakan kalus non embriogenik (Ibrahim et al. 2013).

Tekstur dan warna kalus pada eksplan staminodia klon kakao unggul Sulawesi 1 disajikan pada Gambar 3.

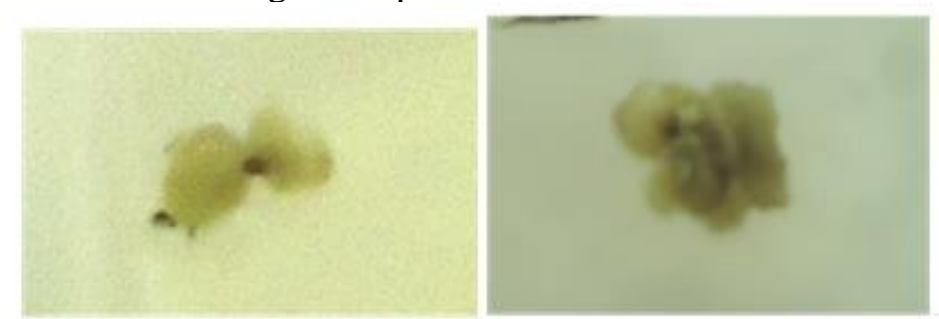

(a)

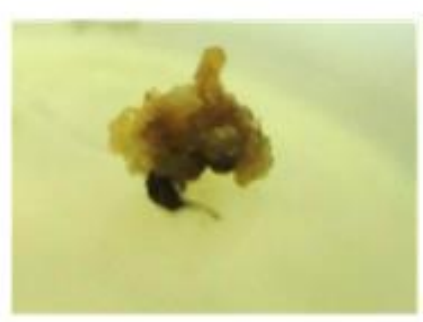

(d) (b)

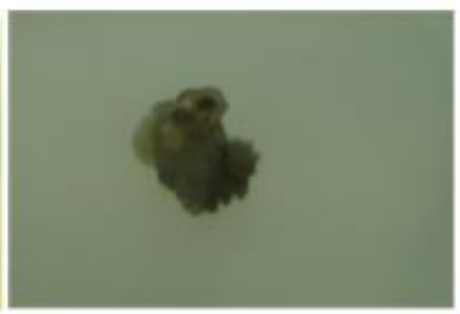

(e)

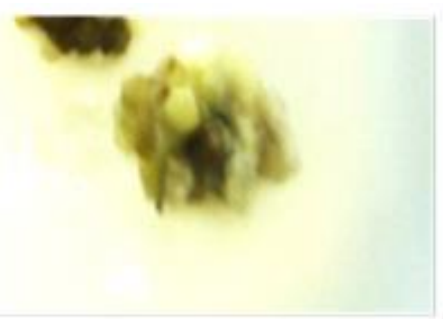

(c)

Gambar 3. Tekstur dan Warna Kalus Staminodia Klon Kakao Unggul Sulawesi 1

Figure 3. Textures and colors of Staminodia cocoa clones Sulawesi 1

Keterangan : (a) Remah putih (b) Kompak, putih (c) Intermediet, putih kekuringan (d) Remah, putih kekuringan (e) Kompak, putih kecoklatan 


\section{KESIMPULAN}

Berdasarkan hasil penelitian maka dapat disimpulkan bahwa kemampuan induksi kalus berbeda pada berbagai konsentrasi 2,4-D untuk klon kakao unggul Sulawesi 1 yang dicobakan. Saat muncul kalus paling cepat diperoleh pada konsentrasi 0,5 ppm 2,4-D yaitu rata-rata 16,67 HST dengan persentase pembentukan kalus tertinggi mencapai $99,33 \%$. Selanjutnya, Warna dan tekstur kalus yang dihasilkan yaitu remah putih dan remah kecoklatan.

\section{DAFTAR PUSTAKA}

Ariati,S.N., Waeniati, Muslimin dan , I.N. Suwastika. 2012. Induksi Kalus Tanaman Kakao (Theobroma cacao L.) pada Media MS dengan Penambahan 2,4-D, BAP Dan Air Kelapa. Jurnal Natural Science Vol. 1.(1) 74-84.

Arianto, Z. Basri dan Bustami, M.U. 2013. Induksi Kalus Dua Klon Kakao (Theobroma cacao L.) Unggul Sulawesi pada Berbagai Konsentrasi 2,4 Dichlorophenoxy Acetic acid Secara In Vitro. e-J. Agrotekbis 1 (3) : 211-220.

Avivi. S., Prawoto. A., dan Oetami, F. R., 2010 . Regenerasi Embriogenesis Somatik pada Beberapa Klon Kakao Indonesia dari Eksplan Bunga. Fakultas Pertanian, Universitas Jember, Indonesian Coffee and Cocoa Research Institute (ICCRI), Jember, Indonesia.

Direktorat Jenderal Perkebunan. 2009. Buku Panduan Teknis Budidaya Tanaman Kakao (Theobroma cacao L.) : Jakarta.

Ibrahim. M.S.D., R.S. Hartati., Rubiyo., A. Purwito dan Sudarsono. 2013. Induksi Kalus Embriogenik dan Daya Regenerasi Kopi Arabika Menggunakan 2,4Dichlorophenoxyaceticacid dan 6Benziladenine . Buletin RISTRI 4 (2): 9198.

Ikeuchi M, Sugimoto K, \& Iwase A.2013. Review: Plant Callus: Mechanisms of Induction and Repression. The Plant Cell, Vol. 25: 31593173.

Kartikasari P, Hidayat MH, \& Ratnasari E. 2013. Pengaruh Zat Pengatur Tumbuh 2,4-D (2,4Dichlorophenoxyacetic acid) dan Kinetin (6Furfurylaminopurine) untuk Pertumbuhan Tunas Eksplan Pucuk Tanaman Jabon (Anthocephalus cadamba Miq. ex Roxb.) secara In Vitro. LenteraBio Vol. 2 No. 1 Hal. 75-80.

Mahadi, I., W. Syafi'i., dan Y. Sari. 2016. Induksi Kalus Jeruk Kasturi (Citrus microcarpa) Menggunakan Hormon 2,4-D dan BAP dengan Metode in vitro. Jurnal Ilmu Pertanian Indonesia (JIPI), Vol. 21 (2).

Puteri RF, Ratnasari E, \& Isnawati. 2014. Pengaruh Penambahan Berbagai Konsentrasi NAA (Napthalene Acetic Acid) dan BAP (Benzyl Amino Purine) terhadap Induksi Kalus Daun Sirsak (Annona muricata) secara In Vitro. Lentera Bio 3(3): 154-159.

Robles-Martinez M, Barba-de la Rosa AP, Gueroud F, Negre-Salvayre A, Rossognol M, SantosDiaz MS. 2016. Establishment of callus and cell suspensions of wild and domesticated Opuntia Species: Study on their potential as a source of metabolite production. Plant Cell, Tissue and Organ Culture. 124(1): 181189. http://doi.org/bpqg.

Sitinjak. M.A., M. N. Isda dan S. Fatonah. 2015. Induksi Kalus dari Eksplan Daun In Vitro Keladi Tikus (Typhonium sp.) dengan Perlakuan 2,4-D dan Kinetin. Al-Kauniyah Jurnal Biologi Volume 8 Nomor 1.

Wahyuningtias. L., R.S. Resmisari dan Naschuddin. 2014. Induksi Kalus Akasia (Acacia mangium) dengan Penambahan Kombinasi 2,4-D dan BAP pada Media MS. Jurusan Biologi Fakultas Sains dan Teknologi Universitas Islam Negeri Maulana Malik Ibrahim Malang. http://etheses.uinmalang.ac.id/376/12/10620033\%20Rangku man.pdf Diakses tanggal 25 Maret 2019.

Widyawati, G. 2010. Pengaruh Varietas Konsentrasi NAA dan BAP terhadap Induksi dan Pertumbuhan Kalus Jarak Pagar (Jatropa curcas L.). Tesis tidak diterbitkan. Surakarta : Program Pascasarjana UNS.

Rasud,Y. 2012. Induksi Kalus dan Inisiasi Tunas Cengkeh (Syzygium aromaticum L.) Secara In Vitro.[Tesis]. Program Pascasarjana Universitas Tadulako. Palu.[Indonesia] 